\title{
Building a Conceptual Framework of Values Capital for Educational Leadership
}

\author{
Chi-Hu Tien \\ Hungkuang University, Taichung, Taiwan
}

\begin{abstract}
What makes a great leader great and what makes a leader become ordinary? Leadership is fundamentally a value-laden activity and values as conceptions of the desirable that guide the way social actors. Values are generally acknowledged to be central to the field of leadership. By reviewing the related literature and analyzing the relevant concepts, this article is trying to bring up a new idea which the author called "values capital" and to build up a conceptual framework for leadership. This study suggests that corporations need to counter the predominant value of self-interest in the global marketplace by proactively managing the ethical context of the organization. Perceived value congruence positively correlated to such affective outcomes as satisfaction, commitment, and involvement and negatively with performance. Organizational leaders can prime different values identities according to which are appropriate for the particular context. Four elements including principle, consequence, consensus, and preference of values are identified to be the keys of the conceptual framework of values for leadership.
\end{abstract}

Keywords: leadership, values, values capital, management

\section{Introduction}

As Willower (1992) pointed out, because a significant portion of the practice in educational administration requires rejecting some courses of action in favor of a preferred one, values are generally acknowledged to be central to the field. A few years ago, when the author was still the director of Tai Chung Costal Community College, two stories caused him to think about the values problem for educational leadership. The first one is about personal political stance. In Taiwan's election year 2004, the Community College Association in Taipei started a speech program aimed at the topic of "New Constitution." Any community college in Taiwan could just join in and get 30,000 NTD fund for each speech without doing anything but arranging the place. Why did some apply the fund and some did not?

The second story happened in a conversation between a director of a community college with religious background and the author. The author told the director that people around his school love dancing, so dancing classes are the most popular ones at his school. Then, the author asked, "Are dancing classes also popular here at your school?" The director answered, "We do not have any dancing class!" The author replied, "How come? There must be some people love to dance and, as I know, every community college has dancing classes more or less." After a while, she finally gave the author an answer, "We just do not think it is necessary and appropriate to offer a dancing class at my school." The author was astonished for a moment. With a deeper thinking, the author figured it out why they do not have any dancing class. One is about their religious image and the other is

Chi-Hu Tien, Ph.D., assistant professor, Department of Cultural and Creative Industries, Hungkuang University. 
that they do not have any pressure to make profit.

It looks true, from the implications of these two stories above, that most practitioners readily acknowledge the impact of values on educational practice. Administrators have become increasingly sensitive to values issue because of the pluralistic societies in which we live and work (Begley, 1996). But the author is curious to ask that how do values really work in the process of decision-making? Can values be simplified to a more clearly analytical unit, like capital?

\section{The Concept of Capital}

In classical economics, capital is one of three (or four, in some formulations) factors of production. The others are land, labour, and (in some versions) organization, entrepreneurship, or management. Earlier illustrations often described capital as physical items, such as tools, buildings, and vehicles that are used in the production process. Since at least the 1960s, economists have increasingly focused on broader forms of capital. For example, investment in skills and education can be viewed as building up human capital or knowledge capital, and investments in intellectual property can be viewed as building up intellectual capital. Ratnapala (2003) indicated that capital generally understood consists of resources owned by individuals or firms and applied in the production of goods and services. These resources include incorporeal assets, such as goodwill, trade reputation, and training. The concept of capital has more recently been extended to conditions that help production by facilitating coordination among parties to transactions. This form of capital may or may not be "owned" by individuals or firms, but it provides them with clear advantages. These terms lead to certain questions and controversies discussed in those articles. Human development theory describes human capital as being composed of distinct social, imitative, and creative elements. Social capital is the value of network trusting relationships between individuals in an economy. If there is a room for values, it should fall within this extended meaning of capital.

\section{What Are Values?}

Values are considered subjective, vary across people and cultures and are in many ways aligned with belief and belief systems. Types of values include ethical/moral values, doctrinal/ideological (political, religious) values, social values, and aesthetic values. It is debated whether some values are intrinsic. Begley (1996) has pointed out that social psychology has long supported the importance of values in people's thinking and seminal works, such as Barnard (1938), Weber (1949), and Simon (1965) certainly acknowledge the function of values. However, the achievement of anything resembling theoretical consensus on the nature and function of values has been elusive. People are surrounded by values, they see what they see by values and they make decisions by values, but they usually ignore that it is the "spring of human action" (Greenfield, 1986). What are values anyway?

Willower and Licata (1997) defined values as conceptions of the desirable and administrator regularly make choices from competing conceptions of the desirable. Haydon (2007) offered another definition for values, attributable in its original version to the sociologist Kluckhohn, which has been cited by several writers on values in educational management: Values are conceptions, explicit or implicit, distinctive of an individual or characteristic of a group, of the desirable, which influence the selection from available modes, means, and ends of action.

With Kluckhohn's definition, some important characteristics of values can be clearly developed as follows:

1. Values are conceptions. Values are not physical objects but ideas about what is important or what matters to each person. 
2. Values may be explicit or implicit. That means in people's choices and actions, they will be influenced all the time by what they take to be preferable or important, whether or not they spell out to anyone else exactly what ideas are influencing them. If a person is willing to tell anyone about what is right from wrong, he/she is making his /her values explicit.

3. Values may be distinctive of an individual. It can be very personal.

4. Values can also be distinctive of a group. Religious community is an example.

5. Values are conceptions of what is desirable.

6. Values "influence the selection from available modes, means, and ends of action." Values will be influencing people in what they do and how they do it, even though they may not have spelled out their reasons for acting in one way rather than another.

This definition explains the characteristics and part of the functions of values, but neither does it explain what constitute values, nor offer an analytical structure. A more detailed, more complicated explanation for values is needed.

Hodgkinson (1978) suggested an analytical model of the value concept, which identifies three types of value, motivational bases that become the source of values, beliefs, attitudes, and actions for individuals. There are values that Hodgkinson thinks can be given a rational justification, by appealing either to consensus or to consequences. Then, at the other end of the framework, there are values that are matters of principle, expressing commitments that (in Hodgkinson's view) go beyond the possibility of rational grounding. Hodgkinson called these values "trans-rational." They might include principles of justice, equality, or dignity. One may think of the principles that Hodgkinson calls "trans-rational" either as fundamental principles that underpin all other values, or as high-level principles that are somehow placed above all other values. Both of these ways of thinking involve a spatial metaphor. So, if we represent Hodgkinson's framework in a diagram, the trans-rational values can be put either at the bottom or at the top.

In sum, four elements including principle, consequence, consensus, and preference of values can be identified through Hodgkinson's framework (see Table 1).

Table 1

Categories of Values

\begin{tabular}{|c|c|c|c|c|}
\hline \multirow{9}{*}{ Right good } & \multirow{3}{*}{ Principle } & \multirow{3}{*}{ Conative } & Religionism & \multirow{3}{*}{$\begin{array}{l}\text { Trans-rational } \\
\text { I }\end{array}$} \\
\hline & & & Existentialism & \\
\hline & & & Ideologism & \\
\hline & \multirow{2}{*}{ Consequences (2a) } & \multirow{3}{*}{ Cognitive } & Humanism & \multirow{3}{*}{$\begin{array}{l}\text { Rational } \\
\text { II }\end{array}$} \\
\hline & & & Pragmatism & \\
\hline & Consensus (2b) & & Utilitarianism & \\
\hline & \multirow{3}{*}{ Preference } & \multirow{3}{*}{ Affective } & Logical positivism & \multirow{3}{*}{$\begin{array}{l}\text { Sub-rational } \\
\text { III }\end{array}$} \\
\hline & & & Behaviourism & \\
\hline & & & Hedonism & \\
\hline
\end{tabular}

\section{Values and Leadership}

Leadership is fundamentally a value-laden activity. Schwartz (1999) defined "values as conceptions of the desirable that guide the way social actors (e.g., organizational leaders, policy-makers, and individual persons) select actions, evaluate people, and events, and explain their actions and evaluations." As values indicate how 
individuals are to adapt to the organization's needs, leaders not only must embrace them personally, they also need to be purveyors of these values to their subordinates.

Schwartz (1992) developed a theory about the structure of value systems by focusing on the motivation represented in each of 10 value types. According to his findings, values are aligned with two motivational dimensions. Using Rohan's (2000) new labels, the first dimension, focus on opportunity $v s$. focus on organization, relates to conflicts between being motivated "to follow [one's] own intellectual and emotional interests in unpredictable and uncertain directions" or "to preserve the status quo and the certainty it provides in relationships with close others, institutions, and traditions" (Schwartz, 1999). This motivational dimension relates to contemporary leaders' need to produce organizational change by developing and communicating a vision, and then, inspiring people to attain it (Kotter, 1990). Therefore, 2 of Schwartz' 10 value types sharing the same underlying dimension (i.e., focus on opportunity) - seeking stimulation (i.e., excitement, novelty, and challenge) and being self-directed (i.e., a creative and curious independent thinker) — appear to be values related to success as a leader.

The second and most important dimension for this study Schwartz (1992) labeled self-enhancement vs. self-transcendence and relates to the "conflict between concern for the consequences of own and others' actions for the self and concern for the consequences of own and others' actions in the social context [i.e., individual vs. collective interests]" (Rohan, 2000). Again, Rohan made use of new labels-focus on individual outcomes vs. focus on social context outcomes. This dimension has particular significance to organizational studies because its poles make a distinction between different value priorities that represent one of the key struggles facing many leaders today. The leader's challenge is to reconcile these tensions.

In recent years, leadership discussions have embraced a more social understanding of "leadership as a complex interaction between the leader and the social and organizational environment" (Fiedler, 1996). According to this approach, leadership emerges out of the social systems and engages everyone in the community in a social process (Barker, 1997). Consequently, social context outcomes have taken on a more central place among the factors that leaders must consider in their decision-making processes. Thus, leading with a focus on social context outcomes, or self-transcendence, is a strategic leadership approach that organizations should strive to engender in their leaders. In a 1998 study of ethical contexts in organizations, Treviño, Butterfield, and McCabe (1998) found that egoism (operationalized as self-interest) had a negative relationship with organizational commitment and a positive relationship with unethical conduct. At the other end of the second dimension, there was a positive relationship between organizational commitment and benevolence to the employees and community. The authors of the study recommended that corporations need to counter the predominant value of self-interest in the global marketplace by proactively managing the ethical context of the organization. This study follows their suggestion as it examines the influence of organizational culture (operationalized as ethical, caring, and supportive culture and leadership) on the development of newly promoted leaders' identities as values-based leaders.

\section{Values and Organizational Culture}

Organizational culture as shared assumptions and beliefs that guide group behaviors (Schein, 1992) suggests that individuals and organizations can share the same values. When values are shared, it is anticipated that the individual is more likely to identify with the organization and be influenced by its values and norms (Chatman, 1989). Robert Haas, the chairman and chief executive officer of Levi Strauss \& Co., suggested that "the alignment between organizational values and personal values is the key driver of corporate success" (as 
cited in Kuczmarski \& Kuczmarski, 1995). Shared values constitute a significant component of an organization's culture and encourage efficient interactions between employees (Meglino \& Ravlin, 1998). From their values in organizations study of empirical literature published between 1987 and 1997, Meglino and Ravlin confirmed that value congruence has a positive relationship with affective outcomes and evaluations. They found this to be true for both actual and perceived congruence of values. Perceived value congruence positively correlated to such affective outcomes as satisfaction, commitment, and involvement and negatively with performance.

Therefore, organizational leaders can prime different values identities according to which are appropriate for the particular context (e.g., individual outcomes vs. social context outcomes). Such priming can occur through the organizational leader's words or actions within an authentic relationship.

\section{Conclusion}

In Planning Responsibly for Adult Education: A Guide to Negotiating Power and Interests, Cervero and Wilson (1994) wrote:

... That planning program is a social activity in which people negotiate personal and organizational interest. The educational programs ... they are planned by real people in complex organizations that have sets of historical traditions, relationships of power, and human needs and interests.

According to social identity theory, "People tend to classify themselves and others into various social categories" (Ashforth \& Mael, 1989). This process is called social identification and entails the "perception of oneness with or belongingness to the social category or role" (Ashforth, 2001). "Goals, rooted in a value system and a sense of personal identity, invest activities with meaning and purpose" (Bandura, 2001, p. 8). Therefore, it is anticipated that those aspiring to leadership will seek to identify with and become part of the existing leader group, affecting their cognitions, values, and behaviors. For Wojciszke (1989), value identities cannot influence behavior unless activated, and organizational leaders are in the ideal position to do so. It is proposed that leaders' value identities are instrumental guides for their values choices, and that organizational leaders can affect different values-based behaviors by activating new leaders' value identities. Above all, the author may conclude a conceptual framework of values capital for educational leadership, as shown in Figure 1.

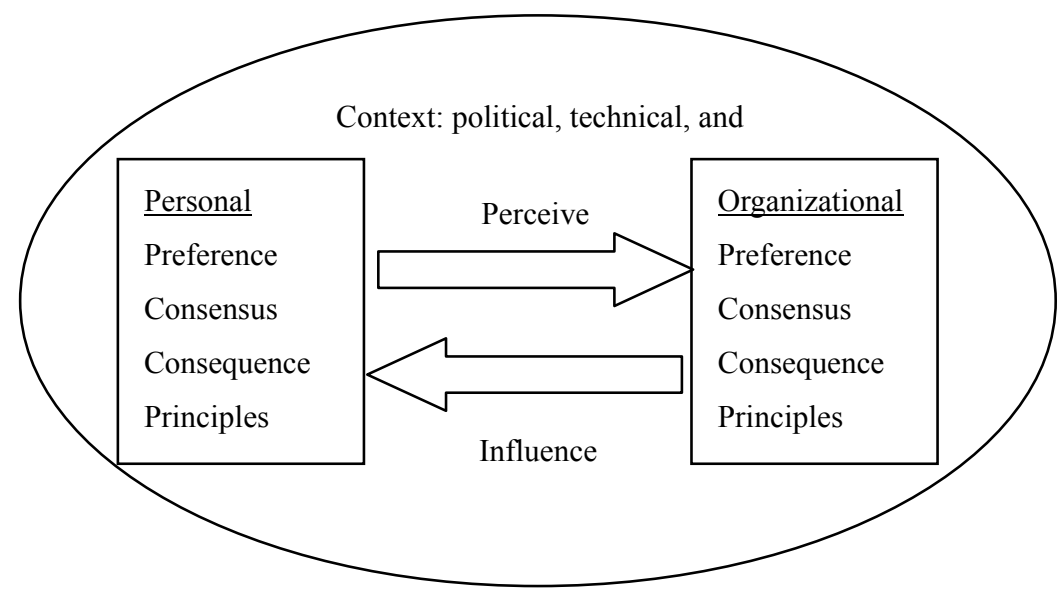

Figure 1. A conceptual framework of values capital for leadership. 


\section{References}

Ashforth, B. E. (2001). Role transitions in organizational life: An identity-based perspective. Mahwah, N.J.: Erlbaum.

Ashforth, B. E., \& Mael, F. (1989). Social identity theory and organization. Academy of Management Review, 14(1), 20-39.

Bandura, A. (1986). Social foundations of thought and action. Englewood Cliffs, N.J.: Prentice Hall.

Bandura, A. (1997). Self-efficacy: The exercise of control. New York, N.Y.: Freeman.

Bandura, A. (2001). Social cognitive theory: An agentic perspective. Annual Review of Psychology, 52(1), 1-26.

Barker, R. A. (1997). How can we train leaders if we do not know what leadership is? Human Relations, 50(4), 343-362.

Barnard, C. I. (1938). The functions of the executive. Cambridge, M.A.: Harvard University Press.

Begley, P. (1996). Cognitive perspectives on the nature and function of values in education. In K. Leithwood, J. Chapman, D. Corson, P. Hallinger, \& A. Hart (Eds.), International handbook of educational leadership and administration (Chapter 17, pp. 551-588). Boston, M.A.: Kluwer Academic Publisher.

Begley, P., \& Leonard, P. (Eds.). (1999). The values of educational administration. London, U.K.: Falmer.

Burns, J. M. (1978). Leadership. New York, N.Y.: Harper \& Row.

Cervero, R. M., \& Wilson, A. L. (1994). Planning responsibly for adult education: A guide to negotiating power and interests. San Francisco, C.A.: Jossey-Bass.

Chatman, J. A. (1989). Improving interactional organizational research: A model of person-organization fit. Academy of Management Review, 14(1), 333-349.

Collins, J. D., \& Porras, J. I. (2004). Built to last: Successful habits of visionary companies. New York, N.Y.: Harper Business.

Fiedler, F. E. (1996). Research on leadership selection and training: One view of the future. Administrative Science Quarterly, 41(2), 241-250.

Gecas, V. (2000). Value identities, self-motives, and social movements. In S. Stryker, T. J. Owens, \& R. W. White (Eds.), Self, identity, and social movements (pp. 93-109). Minneapolis, M.N.: University of Minnesota.

George, B., Sims, P., McLean, A. N., \& Mayer, D. (2007). Discovering your authentic leadership. Harvard Business Review, $85(2), 129-138$.

Gioia, D. A. (1986). Symbols, scripts, and sensemaking: Creating meaning in the organizational experience. In H. P. Sims, Jr., \& D. A. Gioia (Eds.), The thinking organization (pp. 49-74). San Francisco, C.A.: Jossey-Bass.

Gioia, D. A., \& Chittipeddi, K. (1991). Sensemaking and sensegiving in strategic change initiation. Strategic Management Journal, 12(6), 433-448.

Glaser, B. G., \& Strauss, A. L. (1967). The discovery of grounded theory: Strategies for qualitative research. Hawthorne, N.Y.: Aldine de Gruyter.

Greenfield, T. B. (1986). The decline and fall of science in educational administration. Interchange, 17(2), 57-80.

Haydon, G. (2007). Values for educational leadership. London, U.K.: Sage.

Hitlin, S. (2003). Values as the core of personal identity: Drawing links between two theories of self. Social Psychology Quarterly, 66(2), 118-137.

Hodgkinson, C. (1978). Towards a philosophy of administration. Oxford, U.K.: Basil Black-Well.

Kotter, J. P. (1990). A force for change: How leadership differs from management. New York, N.Y.: Free Press.

Kuczmarski, S. S., \& Kuczmarski, T. D. (1995). Values-based leadership. Paramus, N.J.: Prentice-Hall.

Meglino, B. M., \& Ravlin, E. C. (1998). Individual values in organizations: Concepts, controversies, and research. Journal of Management, 24, 351-389.

Ratnapala, S. (2003). Moral capital and commercial society. The Independent Review, VIII(2).

Rohan, M. J. (2000). A rose by any name? The values construct. Personality and Social Psychology Review, 4, 255-277.

Schein, E. H. (1992). Organizational culture and leadership (2nd ed.). San Francisco, C.A.: Jossey-Bass.

Schwartz, S. H. (1992). Universals in the content and structure of values: Theoretical advances and empirical tests in 20 countries. In M. Zanna (Ed.), Advances in experimental social psychology (pp. 1-65). New York, N.Y.: Academic Press.

Schwartz, S. H. (1999). A theory of cultural values and some implications for work. Applied Psychology: An International Review, $48(1), 23-47$.

Simon, H. (1965). Administrative behaviour (2nd ed.). New York, N.Y.: Free Press.

Strauss, A., \& Corbin, J. (1998). Basics of qualitative research: Grounded theory procedures and techniques (2nd ed.). Thousand Oaks, C.A.: Sage. 
Treviño, L. K., Butterfield, K. D., \& McCabe, D. L. (1998). The ethical context of organization: Influences on employee attitudes and behaviors. Business Ethical Quarterly, 8, 447-476.

Tyson, L. D. (2004, February 23). Outsourcing: Who's safe anymore? Business Week, 3871, 26.

Weber, M. (1949). Methodology of the social sciences. New York, N.Y.: Free Press.

Willower, D. (1992). Educational administration: Intellectual trends. In Encyclopedia of Educational Research. Toronto: Macmillan.

Willower, D., \& Licata, J. (1997). Values and valuation in the practice of educational administration. Thousand Oaks, C.A.: Crowin Press.

Wojciszke, B. (1989). The system of personal values and behavior. In N. Eisenberg, J. Reykowski, \& E. Staub (Eds.), Social and moral values: Individual and societal perspectives (pp. 229-251). Hillsdale, N.J.: Erlbaum. 